\title{
Papers
}

\section{Financial and social barriers to bank merger and acquisition}

\author{
Mansour Alshamali, Mansour Alfadly, and Naser I. Abumustafa* \\ *Department of Finance and Economics, Gulf University for Science and Technology, Safat, \\ Kuwait. \\ Tel: + 965 2240130, x5540, Fax: + 9652645795
}

Received (in revised form): 21st June, 2008

\begin{abstract}
Mansour Alshamali completed his bachelor degree in Industrial and System Engineering from the University of Southern California, his MBA from California State University and his doctorate in Finance from the University of Loughbourough, UK. He is Kuwait Vocational Incubator-Advisor, was a senior financial economist with Central Bank of Kuwait, a member of Government Privatization Committee, a consultant to The Amiri Diwan, in State of Kuwait, worked with International Monetary Fund in different projects, represented the Islamic Chamber of Commerce for 57 Islamic countries. Currently, he is Associate Professor and Head of the Banking \& Insurance Department at the College of Business Studies, PAET, State of Kuwait. He has published many research papers, international journals and different text books.
\end{abstract}

Mansour Alfadly got his master's degree from Northrope University, Los Angeles USA and his PhD from the University of Loughbourough, UK with specialisation in Finance. Dr Mansour Alfadly was a consultant for Kuwait Stock Market and also was consultant for the Kuwait Institute of Scientific Research. Currently, he is Associate Professor at College of Business Studies, PAET, State of Kuwait and Cultural Attaché for the Kuwaiti Students in Bahrain. He has published many articles in finance and investment.

Naser I. Abumustafa currently holds the position of Director of the MBA program at Gulf University for Science and Technology. He has written extensively about trading rules, transaction costs, index markets, and stock markets regulation and efficiency. He is the author of 15 articles in leading scholarly journals, including Applied Financial Economics; Development Journal; Journal of Derivatives \& Hedge Funds; Journal of Applied Economics Letters; and Risk Management Journal. He has an international reputation as an expert on Middle Eastern Stock Markets.

\begin{abstract}
This paper presents an empirical investigation of the various social and business barriers to bank merger and acquisition in Kuwait. The investigation contains an assessment of the emerging banking structure and questions the ultimate need to deregulate the banking sector. The study explores the various reasons for the lack of interest in merger and acquisition in Kuwait, contradicting the general trend in the banking industry worldwide. We analyse the performance of major banks and investigate the CEO's perception of banking consolidation and deregulation of this sector. We find that inappropriate
\end{abstract}

market regulations against foreign direct investments, poor internal decision making and governance, high concentration in equity ownership, and inexperienced management dominance are major characteristics of this sector that act against any possible merger attempt, in addition to some other factors. Further, short-term benefits seem to act as secondary barriers to strategic consolidation. Journal of Derivatives \& Hedge Funds (2008) 14, 160-197. doi:10.1057/jdhf.2008.19

Keywords: merger; acquisition; bank; social barriers; foreign direct investment
Journal of Derivatives \& Hedge Funds, Vol. 14 Nos. 3/4, 2008, pp. 160-197 (C) 2008 Palgrave Macmillan 1753-9641 


\section{BANKING STRUCTURE IN KUWAIT (EMERGING PERSPECTIVE)}

In recent years, most literature in the field of banking had been directed towards the study of major alliances in the western world, without paying attention to emerging markets. This situation has led to much more focus on the various benefits and advantages of consolidation in major banking societies and less analysis of various obstacles to this process, since it has not received enough attention from banks in emerging markets. Promoting bank mergers (especially the horizontal in-market mergers) has been the centre of considerable debate in Kuwait during recent years. As we attempted to study the various pros and cons of mergers and acquisitions in banks, we thought it important to explore the Kuwaiti banking structure. The study is divided into three parts: theoretical analysis of this strategy, financial analysis of this sector, and a field study of the top management.

In Kuwait, there are seven national, three Islamic, and three foreign banks (subsidiaries), serving a population of 3 million. In 2008, the total number of branches reached around 250 .

The Kuwaiti banking sector is still far away from any serious move towards financial service modernisation. Most national banks are not yet facing competition from foreign subsidiaries. Taking advantage of cheap and imported technology, products, and financial support all of the national banks they operate in less risk environment where 95 per cent of government employees deposit there salaries through banking system in Kuwait and almost 60 per cent of loans guaranteed by the government salary.

Government ownership in many local banks is considered to be a major financial support to these financial institutions, as all government financial activities are executed through these banks.
To reap the benefit of long-lasting economic expansion in Kuwait, the recent economic slowdown and business restructuring have revealed several weaknesses in this sector, notably in credits. Credit distributions among the different economic sectors during expansion years were miscalculated by some of the banks in this business that are widely considered aggressive. In the coming years, this sector is expected to undergo restructuring, as the Central Bank is pushing for more consolidated vibrant banks. As local banks will no longer be privileged by some government legislation in the near future, there is no doubt that consolidation and rationalisation of this sector will be the main issue for the financial authorities; both local and foreign banks were able to accelerate their revenues by concentrating on both interest rate spread and fees. Kuwait has the dinar as the official currency and $1 \mathrm{KD}$ equals $\$ 3.2$.

Major national banks are facing competition from Islamic banks, other smaller banks, and foreign banks This fierce competition has forced local banks to expand their branch networks. Eventually, such a situation contradicts rationalisation of the existing branch networks' standard procedures used by major banks, which face tough competition in developed countries. Since operating costs and increased efficiency are major objectives for most bank mergers, the Kuwaiti banking system needs to switch its medium strategies to long-term ones. Therefore, in-market consolidation should lead to a substantial drop in operating expenses. Studies by Keefe, Bruyette, and Woods and Ernst and Young $^{1}$ and Houston and Ryngaert ${ }^{2}$ revealed that in-market mergers are a tool for cost reductions ${ }^{3}$ of at least 30 percent in the first year of merger does not harm the quality of services 
provided by both entities before the consolidation.

Some foreign banks in Kuwait operate as subsidiary banks with restrictive branching and capital adequacy requirements. These subsidiaries have an advantage over national banks because they easily acquire cheap technology and have a better variety of banking products and foreign financial services and better access to foreign markets. On the other hand, local banks still use traditional banking services that limit future development and the chance for better competition. As local banks struggle to improve banking efficiency without going into strategic consolidation, the possibility of transferring scarce corporate resources from and to a bank with better abilities to operate efficiently works against the findings by Ravens Cart and Scherer in 1987. They argued that traditional merger theory enhances performance through the transfer of resources between a more efficient bank and another one with weak resources. Despite indirect support for in-market mergers and other kinds of consolidation by financial authorities, there have been a limited number of initiatives by national banks to consolidate. Only a single merger saw the light. This situation is completely different from what is taking place in other banking systems. This study will attempt to shed some light on the different barriers that contributed to banks' failure to consolidate. As it might seem advantageous to some to merge, it is also possible that others will see it as a loss of power, wealth, and prosperity. The failure to enter into such a process might be the result of issues such as conflict of interest, problems of coordination, fear of organisational changes, incompatibility of objectives, and, possibly, management resistance to such change. In the wake of global business changes, operational efficiencies, profit performance, employee productivity and structure, and increasing competition are considered challenges that the domestic banks in Kuwait should carefully take into consideration (Table 1).

Consequently, the financial system of this country will be deregulated. Board members are locals and the top management in most local banks is from foreign banking sectors. There is no doubt that there is a large gap between priorities for both shareholders and the managements, since management always strives to remain in position by increasing shareholders' wealth. Such an achievement would mean that boards of directors are unwilling to see changes in the current structure, as any drastic change would force them to look at the negative side of bank consolidation. ${ }^{4}$

Banks are becoming more concerned about the rapid changes in financial services as the latter poses a threat to them. They also find themselves facing tougher competition because of the globalisation and deregulation of markets in some countries that have eliminated many business barriers and encouraged cross-border banking. This situation raises a major question for banks. Will banks, mostly in developing economies, be able to survive competition

Table 1: Local and foreign banks branches in Kuwait (2005-2007)

\begin{tabular}{lrrrl}
\hline & 2005 & 2006 & 2007 & $\begin{array}{l}\text { Deposits } \\
\text { (dinars) }\end{array}$ \\
\hline Local banks & 250 & 250 & 250 & 7 billion \\
Foreign banks & 3 & 3 & 3 & - billion \\
$\begin{array}{l}\text { Population bank } \\
(000)\end{array}$ & 61.2 & 62.7 & 63.04 & \\
\hline
\end{tabular}


Table 2: Banking sector earnings

\begin{tabular}{|c|c|c|c|c|c|}
\hline & \multirow[b]{2}{*}{2007} & \multicolumn{2}{|c|}{ Earnings in dinar. } & \multirow{2}{*}{$\begin{array}{l}\text { Percentage } \\
2007\end{array}$} & \multirow{2}{*}{$\begin{array}{l}\text { Growth } \\
2006\end{array}$} \\
\hline & & 2006 & 2005 & & \\
\hline \multicolumn{6}{|c|}{ National banks } \\
\hline 1. GB & 90,905 & 91,206 & 92,179 & $(0.23)$ & $(0.02)$ \\
\hline 2. $\mathrm{NBK}$ & 130,452 & 140,797 & 142,475 & $(0.00)$ & 0.05 \\
\hline 3. $\mathrm{CB}$ & 89,783 & 72,739 & 54,212 & 0.23 & 0.34 \\
\hline 4. BKME & 30,040 & 15,846 & 53,089 & 0.90 & $(0.70)$ \\
\hline 5. BK. & 49,320 & 41,450 & 38,743 & 0.19 & 0.07 \\
\hline 6. $\mathrm{BBK}$ & 57,262 & 53,106 & & 0.08 & \\
\hline 7. IB & 55,740 & 56,884 & 58,910 & 0.07 & 0.07 \\
\hline 8. $\mathrm{AB}$ & 70,727 & 73,467 & 75,717 & 0.09 & 0.12 \\
\hline \multicolumn{6}{|l|}{ Islamic banks } \\
\hline 9. KFH & 180,450 & $1,185,645$ & & & $(0.83)$ \\
\hline 10. BB & 42,297 & & & (3.94) & $(0.91)$ \\
\hline Total & $2,897,354$ & $3,048,400$ & $2,394,005$ & $(0.05)$ & 0.27 \\
\hline
\end{tabular}

Data were taken from Annual reports and some other sources.

without looking at building alliances with foreign or local institutions? As competition increases between domestic and foreign banks in a small country like Kuwait, in which interest rates are linked to US interest rates and the local currency has a fixed exchange rate against the US dollar, banks' spread between cost of acquiring funds and interest income from loans is narrowing. Such a situation puts pressure on banks to search for other sources of income, which could result in higher charges and fees.

As shown in Table 2, most banks have suffered a decline in earnings between 2005 and 2007 for many reasons, mainly competition. The high banking concentration, coupled with falling interest margins (the spread between borrowing and lending rates), makes it difficult for banks to sustain high growth. Despite the fact that exceptional performance by banks has been relatively high, rates offered on loans have dropped for many banks in the past few years because competition is increasing and the search for liquidity has become a reality after many years of highly liquid economy. Other banks were able to sustain higher return because they have access to cheap funds (mainly government and public funds). This result is consistent with the existing wisdom that a bank merger can be an excellent long-term strategy for banks in the region. Oil revenues are still considered a source of business growth for this sector. Further, banks do benefit from a large portion of deposits in non-interest-bearing accounts for 
religious reasons. In the changed environment of 1998 and after, banks faced immense challenges.

\section{CURRENT ISSUES IN EMERGING MARKETS}

Emerging financial markets (including the Kuwaiti market) are characterised by weak transparency by financial institutions and financial disclosure, which is leading to weak assessment by investors and shareholders and to an information crisis. Inadequate disclosure, weak corporate management, and control characterise the financial market. Several outcomes can be cited for harsh competition between banks: inappropriate business expansion, inefficient allocation of bank credit, and poor internal governance.

This section of the study examines whether bank mergers can lead to superior performance and to more diversified business strategies, and whether banking strategies applied in western countries can be compatible with banking strategies in the less developed countries. Obviously, what can be seen as appropriate for some developed countries might not be deemed suitable for other financial systems. Mergers have been considered a major vehicle for change in the banking industry in different parts of the world. It is believed that mergers have permitted banks to strengthen and expand their banking services.

Despite recent mergers and acquisitions in most developed markets, several researchers ${ }^{5}$ still argue that these mergers have benefited neither the public nor the acquiring banks, although management and stockholders of acquired banks seem to have gained some benefits. Despite these arguments, bankers in the US and Europe still perceive mergers as a strategic solution to many of their business difficulties. Within this context, the question to be raised is whether banks in Kuwait are structured well enough to perceive mergers as a strategic choice for many of their banking deficiencies. As proposed by Williamson in a 1985 study, the transaction cost theory, the optimal structure of a firm, depends on its institutional context. This context looks at stronger capital structure, management, and product markets. In contrast, emerging financial markets are characterised by inadequate disclosure of financial data, few products, and limited market accessibility. The business of financial intermediaries in Kuwait is still in its preliminary stages. Mutual funds, venture capitalists, and investment banks have not been fully developed in this region. This weak scenario has allowed major international intermediaries to take advantage of the weak financial institutions and allow billions of dollars to be transferred to major financial markets, especially the US stock exchange. ${ }^{6}$

Consequently, Kuwaiti banks are in the process of deregulating the economy as a means to attract foreign investments. It becomes apparent that the gap is increasing between economic growth and capital flights as an outcome of undeveloped financial structure. The new regulations of 2007 are an indicator of weak financial structure. The nonexistence of fixed income market and money market instruments, in international standards, have dramatically reduced investment portfolios for local banks in comparison to Islamic and foreign banks functioning in Kuwait. Further, the absence of an advanced financial structure has led to a 'higher cost of acquiring necessary inputs such as technology, products, and efficient management. The risk exposure for most banks because of few investment opportunities has seriously increased 
due to more credit concentration in certain economic sectors. As a result, some banks have not received high credit ratings by major rating companies such as Standard and Poor's.

There is a general consensus that the scale and scope of banks could help banks in handling the cost of replicating the functions provided by financial institutions in advanced financial markets or at least in following their league. Despite the fact that the expansion of the banking structure through mergers can lead to lower cost through diversification, there are various reasons to believe that the cost of the merger itself could exceed the potential benefits (see Calomiris ${ }^{7}$ ). We could argue that such findings of the costs and benefits of bank mergers cannot be generalised, as we ought to study bank mergers case by case and try to see the various reasons for such alliances. Phenomena such as special interest groups, family ownership, and government ownership in most local banks have worked against potential mergers because most of these groups have conflicts of interest. In general, these controlling groups represent between 65 and 85 per cent of total shares in some banks in the UAE. Therefore, the speed at which the privatisation process will proceed could play an important role in changing the current shareholders' structure and could definitely give banks the ability to reform their business structure and strategic decisions. 8,9

There is a great need to examine the economic causes of bank mergers and their differences from one country to another. What are the possible social consequences of the mergers? Several studies in this field argue that bank mergers have failed to show substantial improvements in efficiency, but they were successful in enhancing diversification, reducing operating expenses, and developing a better customer base and relationship. ${ }^{10,11}$ Furthermore, how long would it take stock returns and bank performance before and after the merger process to show evidence of better efficiency, less operating cost, and a better customer relationship? As we study a banking system where merger cases have taken place only in the last decade, it is difficult to come up with an econometric answer to this. It would be beneficial to our analysis to take evidences and conclusions from mergers that took place in the 2000s.

Despite the conflicting results from different studies of the possible outcome of the consolidation wave in the 1990s, there has been a general conviction that consolidation is the child of competition and the mother of efficiency. ${ }^{7}$ On the one hand, it is true that achieving growth through mergers and acquisition requires planning focused on revenue improvements synergies, and on the other hand that cost reduction must be the essence of this strategic merger. Some researchers have argued that cost reduction might not be a building block, as it will not achieve high growth.

Nevertheless, in order to maintain long-term growth, it is imperative to acknowledge cost reduction measures as a strategic objective. In the wake of mounting competition in recent years, a large number of corporations have used restructuring measures' growth mainly through cost reduction and by eliminating all nonproductive activities and only focusing on core business. In fact, a merger aimed at improving revenues must also look at cost reduction as an ultimate outcome.

In most recent merger intentions, financial markets showed little interest in merger news because the stock price's reaction to merger announcements was negative. In 2005, two 
banks in Kuwait announced interest in merging and had serious meetings to evaluate each bank. The market reaction to this unprecedented move was more or less indifferent, as investors were unfamiliar with the implication of bank mergers and their effect on shareholders' wealth. In sum, it became obvious that the market perception of such a deal was unclear at that time. Investors also seemed to be unaware of the wisdom behind this consolidation. At this point, it became clear that the concept of merger was unknown to investors and markets, especially the long-term benefits.

It is also important to point out that in most mergers, management on both sides, as they announce their alliance, tend not to reveal the true objectives of this alliance and why both boards of directors have agreed to initiate such a difficult and lengthy process. In fact, they tend to provide the market with a vague analysis. In most consolidation announcements, investors seem to be concerned about the time horizon over which the benefits of a merger can be achieved. Therefore, their first reaction shows disappointment and less interest in holding the stock. In many mergers, we have seen that they were made between two banks that are similar in terms of assets, management, and profitability. The true reason, however, had to be the knockout major competitor. It is possible that these alliances will be announced between two banks, with different sides of the banking business aiming at competing with a third party whose activities are more comprehensive. The market should consider a merger like this one as a positive strategy for both parties, as it contains many synergies. In the case of the Kuwaiti banking system, such a consolidation has the potential to develop certain synergies, including operating expense reduction and improved management structure, as the duplicate functions are eliminated.

\section{The possible outcome of strategic alliance and merger barriers in emerging markets}

In general, strategic alliances have different objectives and in most cases there must be multiple objectives for each alliance. In the case of the Kuwaiti banking sector, the probable objectives can sometimes be similar to those in the US or Europe. Nevertheless, other objectives can be added, as this sector still functions in an economy where cross-border regulators do not permit consolidation.

The following is a list of possible objectives and forms of bank consolidation:

1 The merger has the objective of improving the value drivers in the banking sector because it tends to provide quality services and management, broad customers relationship, proprietary distribution, preeminent brands, size and scale, and global existence (cross- border alliance).

2 The merger could introduce a new entity with unmatched origination and better marketing and distribution skills (domestic alliance).

3 The merger would lead to a wider range of products, more experienced management that comes from more developed banking systems, and would enhance private banking, as this business is widely dominated by foreign companies and higher productivity due to better expansion (requires both local and global consolidation).

4 The merger would build a new entity with a stronger and more powerful asset management base. 
5 Multiple channels and brands could be created so that business can compete on different levels (cross-border expansion).

6 Concentration can always lead to better management and ability to compete (domestic alliance).

In this context, the process searching for an international partner is seen as crucial to domestic banks, since the process would enhance cross-selling synergies, open the way to new markets and products, improve management skills, and, more importantly, reduce operating expense. Undoubtedly, local banks are free to search for a foreign partner to form an alliance with but, in reality, there are many economic and social barriers to this strategic move. As Kuwait is preparing to join the World Trade Organization, it is imperative that the government tables a massive piece of legislation that will change the entire financial system in general, and the banking sector in particular. This legislation should amend the rules for local and foreign ownership in domestic banks, and allow for more freedom in selecting partners from inside and outside the country. The government should make it clear that it favours strategic consolidation, in light of recent globalisation efforts. It could be the case that nobody wants to think of this issue as long as banks are achieving their best profit rate ever realised. Calomiris ${ }^{7}$ finds that deregulation can be the most important element affecting merger decisions. By applying the return on equity, interest margin, and income on assets, Calomiris was able to show that aggregate bank performance in the 1999 has been substantially productive, as results were much higher.
Obviously, the amendment of ownership rules to simplify the merger and acquisition is imperative for any cross-border alliance. Such a drastic move would allow banks to diversify their credit portfolio and reduce their risk exposure, given the fact that many of these banks are sitting on excess liquidity in a financial market where money market instruments are almost nonexistent. A merger, in this regard, can lead to what economists called 'value creation' through relationship enhancement. The flow of capital from one side to another, the improvement in customer services, the diversification of banking products, and the multidimensional integration between banks through mergers should lead to a diverse and continuous source of profits for these institutions.

As for major barriers, several studies were able to show that management can play an important role in favouring mergers and making them succeed. It is well known that bank consolidation is set to reduce costs by implementing job cuts, especially in areas where the new entity has a duplication of duties and positions. Therefore, in a banking system where 75 per cent of employees are foreigners working without sound social security protection or retirement plans, they can never be motivated to support any consolidation plan that would lead to a serious reduction in jobs. In this regard, any talk of a merger would launch a series of worries within the parties concerned and the result would be that one of the two managements would realise the threat of such a strategic move and know that it has to vanish at a later stage. The biggest obstacle for the banks would be that the merger would not pose a threat to either management. This is not the case, however, since the main objective of any consolidation is to trim excess jobs and increase the number of 
locals joining this sector. Lately, it has become obvious to the top management that the medium and lower management create natural barriers against locals who join this sector. The mounting competition is an important indication as to how efficient the management is and how effective it can be in handling drastic changes in the banking sector. The existence of mergers would definitely expose weak management as negative financial results start to surface. In the absence of qualified banking management, there are some difficulties in making the proper comparison to see the difference between the current management and the potential one that could be available through consolidation. Clearly, the economic prosperity, the existence of excess cash, and the supportive monetary policy are delaying some banking crises because of weak management. ${ }^{12,13}$

It is considered a shocking idea for many shareholders and boards of directors that some banks would have to disappear from the banking arena, as they tend to consolidate with others. This idea has been difficult to accept, as many shareholders and public figures do not seem to understand the conceptual factors behind it. Given the exceptional gains in the banking industry in Kuwait, it is difficult for many to accept the fact that the long-run outlook for this industry might not be the same in the future when markets open for direct foreign investment. Many bankers use the examples of some failed alliances worldwide as a way of defending their opposition to bank consolidation. In fact, inefficient management tends always to reject this strategic decision, as it represents a threat to their existence at the top of the institution. Efficient institutions can always acquire inefficient banks.

\section{Theory and concepts}

It has been argued that several mega-mergers that took place in the 1990s have resulted in significant cost reduction in line with premerger plans. In contrast, unexpected difficulty in integrating data processing systems and operations was a serious issue to tackle. There are two possible sources of cost savings due to the growth in the size of banks: (1) economies of scale, which mean that a doubling of bank output for any service or package of service will result in less than a doubling of bank production costs because of greater efficiencies in using the bank's resources to produce multiple units of the same service package; and (2) economies of scope, which imply that a bank can reduce operating costs when it expands the mix of its output, because some resources, such as management skill and plant and equipment, are more efficiently utilised in jointly producing multiple services rather than just turning out one service from the same location because fixed costs can be spread over a greater number of different service outputs (see Peter S. Rose). Most recent research efforts suggest that a bank's average cost curve (the relationship between bank size and the cost of production per unit of bank output) has a $U$ shape but appears to have a fairly flat middle portion. Such a concept means that a wide range of banks fall close to being at maximally efficient size, with larger banks typically offering many more services.

Consequently, some bank cost studies have attempted to show the average costs for smaller banks separately from their cost calculations for larger banks. Researchers like Rose and Calomiris suggest that smaller and medium-sized banks tend to reach their lowest production costs.

There is more of a need to question the existence of many banks with much larger size 
than that of any of these so-called optimal size levels. Banks in recent mergers have claimed substantial 'cost savings' flowing from their merger. Indeed, it may be true that the optimalsize operating point in banking is a moving target, increasing as new laws and new technologies come into existence favouring even larger banks. Is a bank, regardless of its size, operating as efficiently as it possibly can? Given the size of a bank, is it operating near to or far away from its lowest possible operating cost? Another way of posing the same question is to ask whether the bank is currently situated along what economists would label its cost-efficient frontier, with little or no waste. To date, research evidence is not encouraging. This suggests that most banks do not operate at their 'minimum possible cost.' In many cases, banks, through the merger strategy, were able to reduce overall operating expense. This discussion implies that most banks could gain more from lowering operating costs at their current size than they could from changing their scale of output in order to reach a lower cost point on their average cost curve. Thus, to be sure, larger banks seem to operate closer to their low-cost point than many smaller banks, probably because the larger institutions generally operate in more intensely competitive markets. ${ }^{14,15}$

In the case of domestic banks in Kuwait, the question of improving efficiency through mergers might not be as much of a concern for many banks as the need for substantial cost reduction, new products, and better risk control procedures. Hence, it is quite clear that horizontal mergers, the type of merger thought to be the most likely to suit Kuwaiti banks, might not assist in achieving banks' strategic objectives. The question that should be raised at this point is whether the horizontal merger might not represent the strategic objective for achieving cost reduction, introducing new products and markets, and improving risk control mechanism. Therefore, what is the possible consolidation mechanism to be considered by the banks in question?

Taking into consideration the financial performance of most local Kuwaiti banks during the past few years, we can easily point out that the issues of profitability and performance were not as much of a concern as credit control and product development (see financial performance section of study IT). Since most of those banks have demonstrated extraordinary performance, it is worth mentioning that such exceptional performance can be attributed to high growth. Since most of those banks have demonstrated extraordinary performance and profit, it is worth mentioning that such exceptional performance can be attributed to high growth in Gross Domestic product (GDP) and the widening margin between interest earned and interest expense. In contrast, the down trend in economic growth should force a large number of local banks to search for an acceptable equation between overlending and the level of charges against doubtful debts. The harsh competition between local and foreign banks functioning in the Kuwaiti market is becoming a point of concern for local banks, as foreign banks have free access to products, foreign markets, and technology.

Therefore, in studying the question of the major long-term advantages of a merger, the other types of mergers such as financial managerial conglomerates or vertical integration, in this preliminary stage, seem to be the most productive in our case of local Kuwaiti banks. As an outcome of such integration, cost cutting, especially in operating expenses, must 
be the result of the immediate lay-off of unnecessary bank employees, a reduction in the number of branches, and the selling of all unneeded fixed assets. As a result, the returnon-assets ratio should increase due to a cut-back primarily in fixed assets. Such an outcome might lead to short-term improvement in efficiency and probability, which contradicts some of the work carried out by others on the same issue. Others, such as Linder and Crane, ${ }^{16}$ suggested that in order for efficiency to improve, there must be a substantial decrease in costs that would offset any decline in assets (return). The most direct conclusion we can draw from this discussion is that for a merger of similar size, the question of reducing operating expenses and other costs is considered a short-term strategic decision, while the increasing efficiency is a long-term objective. Stephen Rhoades ${ }^{17}$ suggested that economists have concluded the following after meeting with bankers ${ }^{18}$ :

- On average, 50 per cent of cost reduction takes place in the first year and the rest will be achieved in the following two years.

- Most significant cost savings were achievable without a merger.

- All cost reduction and efficiency gains should be observable in public financial data.

- A merger is a strategy that can be considered for more than one possible outcome.

Despite the above results, the expected outcomes of bank mergers might not seem to be as productive as was hoped. It is worth noting that the large numbers of mergers we have witnessed in the last ten years contradict the previous conclusions. In addition, the large number and scale of mergers seem to indicate that the objectives of mergers exceed by far the cost-cutting and efficiency-improvement decisions. As explained earlier, bank mergers should be analysed case by case for the following reasons:

- The financial system for each country has its own structure, which could directly affect the outcome of each merger.

- The globalisation of financial activities implies that the needs and duties of banks have substantially changed to match international standards.

- In most cases, the short-term results of bank mergers do not correspond with pre-set objectives.

- Mergers should always take place when both the acquirer and the target bank are at their best stage of financial performance.

- Most mergers that occurred in recent years were between large banks, which supports our assumption that there are more important objectives than just efficiency improvement and cost reduction.

Therefore, these two objectives are important, although they do not appear among top bank priorities.

Furthermore, the mergers of large banks with significant office overlap, which took place in the last ten years, were designed to achieve more complex objectives such as reducing competition and expanding capital and assets, in addition to improving credit structure for both the acquirer and the target bank, and different market concentrations. For these reasons, the concept of mergers has evolved over the past two decades. It includes takeovers, issues related to corporate restructuring, corporate control, and change in the ownership structure of firms. Therefore, the mergers issue poses important 
questions for shareholders, the management, and public policy formulation.

The merger process is vital for the healthy expansion of banks as they evolve through successive stages of growth and prosperity. Ultimately, bank mergers in Kuwait go beyond the objective of entering new geographic markets and probably other goals. It is essential to accompany the major economic improvements in the region and the latest business expansion with multinational corporations (MNCs) and trade alliances in the region. As local banks, to some extent, have been unable to develop their financial products at the local and international level, they may be left behind in terms of competition, as billions of dollars were invested directly through foreign banks. It became evident to many economists ${ }^{5}$ that a merger is a strategic process that should lead to a stronger balance sheet, the use of advanced technology, more efficient management, and substantial cost cutting. On the other hand, others could argue that these advantages might not be the reason behind mergers, as most recent merger intentions have a poor position between different banks with equivalent resources and quality. This would lead us to the possible conclusion that in most merger cases, there must be a set of objectives that both sides of the process hope to achieve. As we seek to sort out the different theories, views on the advantages, and aims of bank mergers in emerging markets, which are far off from the European or American models, we will show that each merger should be separately analysed, as the aims and benefits are not necessarily comparable to other mergers. Aims and reasons could differ between one merger and another.

\section{Bank merger}

From an economic standpoint, the structure and efficiency of bank mergers should not be derived from the four different categories of merger. The reason for this contradiction is that, regardless of the purpose of this strategic decision, what really concerns us most is the viability and outcome of the merger. Clearly, whether the immediate decision to merge is related to horizontal, vertical, conglomerate, or financial integration, the success of the merger rests primarily on the coastlines of market mechanism and contracting. On the other hand, second-stage success rests also on the willingness of either party to dispose its managerial and financial structure for the benefit of using the other party management model. Mark Guzman ${ }^{19}$ confirms that banking monopolies tend to reduce an economy's social welfare, as they charge higher prices and waste resources through inappropriate expansion.

Moreover, even in a more competitive market, banks are still facing two major issues: the lack of information concerning individuals requesting financing, and the quality and types of projects they wish to undertake. Guzman has used both the partial equilibrium model and the general equilibrium model to focus on the particular aspects of the bank-borrower relationship. Both models are excellent for ascertaining whether the costs outweigh the benefits of monopolistic banking. From an emerging market perspective, there is a great need for banks to search for a strategic alliance, as the banking system is still in transition. One important type of integration that can be considered crucial in our case is the 'international integration type'. The most critical issue that local banks must face in the future will be stopping funds from moving outside the region. Without going into too much detail, the international integration could 
provide various benefits to both local and foreign banks. Such an alliance should lead to improvement in productivity, technology, return, management, and ownership.

The four factors mentioned earlier can be considered the most urgent questions to be answered, since the regional economy is heading towards globalisation and, in turn, privatisation. As for the first and second factors, there is no doubt that all local banks in Kuwait were unable to develop their productivity to a level where it could efficiently handle the exceptional business expansion in the last decade. The productivity process is directly related to the type and quality of products used by banks in their approach to promoting their services. In this regard, it is important to indicate that most banks were unsuccessful in product development such as design, testing, and making local market-suited products. Therefore, most used products are a copy of products implemented in other developed markets. Banks attempted to copy various products used in foreign financial markets without knowing their long-term effect on their own credit control or customer satisfaction. For the reasons mentioned before, local banks at some point will be in need of both horizontal and vertical integration.

Banks were unable to develop their own investment subsidiary as a means to penetrate one of the most lucrative businesses worldwide. Consequently, major global investment companies have established some kind of base in the Kuwaiti market, in which billions of dollars were unable to find the best investment opportunities at the international level through the local banking system. As for the technology factor, the high cost of this factor has forced banks to allocate substantial funds to acquire used technology from different markets. The lack of international integration has prevented banks from having proper and inexpensive access to products and equipment. Because of this market structure, local banks did not properly address the risk reduction factor through an efficient and affirmative credit and investment policy. While banks have salutary effects on consumers' access to credit and on banking costs, these effects are not enough to explain why banks have been merging at a high rate in many markets. ${ }^{5}$ Hence, the objective of reaching greater operating efficiency is probably not the only priority in bank mergers.

The financial definition for bank mergers, in our case, and according to our previous discussion, can be easily identified and distinguished. The question of serious shortage in liquidity has not surfaced in the last two decades for several reasons. First, the central bank has followed a stable interest rate policy, since the Kuwait dinar has an almost fixed rate. The official interest rate of Kuwait is linked to the US discount rate. Secondly, the GDP provided an average GDP growth of 7 per cent and the central bank did not have a tight grip on money supply. Thirdly, the central bank did not succeed in creating and developing a real money market in order to have better control on money supply and inflation levels. The bond market and short-term money market instruments do not exist. As a result, banks did not have access to other kinds of investment opportunities as an addition to direct loans to customers.

Therefore, the financial objective of a bank merger can best serve, in our case, as a risk-over-return ratio through diversification. It could serve other strategic objectives, such as providing better planning and control mechanisms, by having improved quality of functional and general managerial performance. 
The concept of economies of scale and ex-efficiency in relation to operating expense control can never be ignored as imminent goals of mergers, especially mega-mergers.

\section{Organisational structure and performance}

One of the principal reasons for a bank being organised in a particular way may not appear to affect its performance significantly, due to the wide variety of management styles and capabilities among banks of all sizes and organisational structures. This is the case of Kuwait, where different managements come from different banking systems and origins.

Some bankers are strongly profit-motivated and expense control conscious. They can often push their banks towards earnings success regardless of how their institution's organisational chart looks. Other managers may prefer greater bank size or possibly greater bank safety to be at the top of their list of objectives, and their bank's earnings performance may take a back seat consequently. In fact, there is evidence of considerable expense-preference behaviour among some bank managers, who value fringe benefits, plush offices, and ample travel budgets over the pursuit of maximum returns for the bank's stockholders. Such expense-preference behaviour may show up in the form of bank staffs larger than required in order to maximise profits or encourage excessively rapid growth, which causes expenses to get out of control. Some economists believe expense-preference behaviour is more likely in those banking organisations where management is dominant and the stockholders are not well organised.

The concept of expense-preference behaviour (cost consciousness) is part of a much larger view of how modern corporations operate, called agency theory, which analyses relationships between a firm's owners and its managers, who are agents of the owners. Agency theory explores whether mechanisms exist in a given situation to compel managers to act in order to maximise the welfare of their firms' owners. If bank owners do not have access to all information with managers, they cannot fully evaluate how good the management was at making decisions. In commercial banking, ownership increasingly spreads out, and the dominance of individual stockholders in the industry appears to decrease. These two trends are likely to worsen any agency problems that may be present in the banking industry. On the contrary, the Kuwaiti banking system is still characterised by great dominance in family ownership and high concentration in shareholders' base. One way to reduce costs from agency problems is to develop better systems for monitoring management behaviour and strong management incentives suiting stockholders' wishes. In retrospect, the success of any merger process can never be possible without a comprehensive evaluation of the potential mergers before its official announcement. Banks must always relate the successes of their integration attempts to several conditions that must be satisfied. Despite the fact that many researchers do not see the economic or financial benefits of the merger decision, there is no doubt that reality contradicts those findings, as the number of announced mergers is increasing tremendously, especially in the United States and Europe. Kay, ${ }^{20}$ in 1993, found that in many merger cases, while the levels of profitability before and after integration were almost unchanged, the objectives had changed. Some of these changes in economic and business structure have led to the following concerns: 
(a) The globalisation factor has forced managements to think globally and to adapt different strategies used by companies from different countries. Just by looking at corporate planning, we can clearly that companies designed their image to fit global standards rather than local or regional ones. They currently focus on a wider range of strategies, such as global strategy, global industry, global management, and global competitiveness. According to Jatusrpirak et al., ${ }^{21}$ a major stimulus to this growing emphasis on international planning has come from the 'Oriental challenge' to western business. (b) Resources, competence, capability, and competition are becoming global challenges rather than domestic or regional. According to the school of thought that looks at resourcebased theories of strategic management, the success of the management is a result of its ability to manage its resource inputs in developing core competencies and distinctive capabilities rather than positioning itself in relation to its industry. The organisation must then exploit these competencies in a variety of markets. Outsourcing, joint ventures, and acquisitions were among other strategic decisions many corporations applied in the 1990s. (c) Increasing competition has made it difficult for companies to safeguard their competitive advantage, and for this reason companies are forced to develop and leverage core competencies that can provide the new type of customers (mostly sophisticated) with the most highly advanced type of products. (d) The search for growth through undiscovered markets has forced companies to look for strategic alliances. These alliances do not necessarily exist at home. Therefore, consolidation is expected to become a major concern for shareholders as it could lead to a drastic change in organisational objectives. ${ }^{22}$
Customers are becoming more sophisticated as the level of technology, services, communication, and know-how has tremendously improved. Customers everywhere in the world are becoming similar when it comes to needs and demands. Although there are similarities, companies must take into consideration some differences in culture and other business factors. The different business barriers can no longer protect domestic businesses from foreign competition, as it takes a local customer living in Kuwait 2 min to buy shares on Wall Street or to renew a deposit in a bank in Europe or in the United States. There is no doubt that the new technological and communication advancements have created a second kind of competition that did not exist before. $^{23}$

\section{PRIVATISATION IN KUWAIT}

Despite the high prices of oil, the Kuwaiti economy has exhibited moderate growth rates in the 2000s. In most recent years, a 7 per cent growth in GDP was easily achieved for two major reasons: the continuous increase in government expenditure, and private sector capital expenditure. Foreign direct investment has participated in this economic expansion in Kuwait as some multinational companies began to establish a regional base in Kuwait since it tries to become financial centre of trade for the whole region. Multinational sourcing became an evident feature of the Kuwaiti economy as foreign corporations established production operations to serve the area. Multinational sourcing became an evident feature of the Kuwaiti economy as foreign corporations established production operations to serve the area specially with the existing of American 
Military in Iraq. In addition, the Kuwaiti market has provided... in the region.

On the other hand, and similar to other 'emerging markets', the Kuwaiti banking market has failed to develop a highly sophisticated capital market that would help corporations to have access to various sources of financing, especially for long-term capital expenditure. The stock market did not have much impact on alleviating major weaknesses in the equity market. One of the characteristics of this market is the high volatility caused by high concentration in equity ownership, thinness of trading, and the inaccessibility of this market for 60 per cent of the Kuwaiti population (expatriates living in Kuwait). Privatisation can improve productivity and efficiency in stateowned enterprises (SOEs). The issue of privatisation in Kuwait has been open for debate for the last 12 years, since the most lucrative sectors of the economy are still denied to foreign direct investment. Therefore, it is unlikely that communication, oil, financial, and other sectors would be 100 per cent accessible to foreign investment or fully owned by the private sector before joining General Agreement on Trade in Services (GATS) in the near future. ${ }^{24}$

Obviously, delaying the privatisation process is not in the interest of the state-owned companies. The reason for this is that privatisation should put ahead few challenges in face of local bank, since the latter must work on improving productivity, efficiency, and reducing expenses, probably through restructuring, before they become competitive to a certain degree. Some of the challenges can be summarised as follows:

1 Management needs to redefine their business strategies, as they are no more in a monopolistic market.
2 Management must realise that the privately owned corporations require a complete change in organisational structure, as financial performance and productivity are always at the top of their objectives.

3 Management must enhance their performance, as government support is no longer possible under the new market rules and structure.

4 Management must be prepared to face corporate takeover, as the new market conditions allow for such consolidation.

Therefore, local banks must conceive of the new market conditions as a major threat, since they compete against large international banks rather than some foreign subsidiaries, as is the case now. Under the new conditions, domestic banks will no more benefit from the tax relief that they currently enjoy.

Some of the points of concern that require elaboration as we attempt to analyse merger and acquisition through the process of privatisation are the efficiency of the stock market and the management structure in Kuwait. Given the fact that the Kuwait stock market was only recently established, there is no doubt that the market is not well prepared to handle huge transfers of ownership from the public and private sector to foreign ownership. In addition, rules and regulations would require amendments, as they were introduced in a more restrictive market that is closed to any foreign investment.

Therefore, such market conditions can work as an obstacle to any capital formation and the emergence of new companies. Undoubtedly, a strong and efficient market is crucial for all kinds of economic restructuring, which are unachievable without improvements in the business environment in Kuwait. For this 
purpose, macroeconomic stability must be achieved so that it can highlight the country as a good location for healthy investment. In this sense, the country must apply several rules and laws that can be considered contributive to foreign and domestic investment, such as standards for corporate governance and investment protection, better employment and welfare conditions, legal and administrative frameworks for property rights, and clear standards of business ethics. By looking at some of the laws and rules in Kuwait, it is possible to say that some of these business conditions were implemented in the past few years.

Despite its relatively short existence, the Kuwaiti stock market is equipped with the most advanced trading techniques. The volume of trading is still very thin, as investors are still recovering from a strong decline in all shares traded on the stock exchange. Most shares have lost all their gains, since they reached the peak in summer 2006, and some are below their intrinsic value. Investors and financial authorities are searching for a solution to this serious decline in shares and any new companies in the primary market were called off due to the weakness in capital formation and overall business performance. Consequently, the market will not be able to witness any business transfer from private equity to public shareholding companies, as many family-owned businesses are trying to go public.

Economists such as Uhlenbruck and Castro ${ }^{25}$ generally support the idea that transferring State ownership to the private sector should improve the overall performance of the economy. This suggestion seems to be favourable in countries where natural resources and major participants in GDP are heavily owned by the state. In recent years, a few governments have turned to privatisation as a solution to reduce their high public debt and reduce pressure on their annual budget financing. Unlike Kuwait, which benefits from oil revenues, many developing countries find privatisation a fast solution to their incremental budget deficit. We should also emphasise that in many cases, the process of privatisation is a forced decision by international financial authorities as part of a package financial plan to support a country's ailing economy. In retrospect, there are various reasons for which developing countries would adopt privatisation and there is no doubt that privatisation has proved to be effective in solving many financial and management problems. ${ }^{25,26}$

\section{The synergy factors}

Another possible issue that is considered extremely important is the timing of the process of privatisation. Therefore, we could classify privatisation into two categories: forced and voluntary. In most developed financial markets, a bank merger is considered a forced one, as market forces, regulation, and particularly tough competition tend to force banks to look for consolidation as a means of improving their financial structure and market position. On the other hand, in most developing markets, the concept of consolidation might not be seen as ideal since it also means loss of power and control to some interest groups. In regard to merger and acquisition, many researchers like Haspeslagh and Jemision ${ }^{27}$ have argued that value capture and value creation are the key and major objectives in acquisition, as the latter should improve shareholders' wealth.

Through privatisation, firms have the opportunity to capture value by acquiring cheap 
assets, even below their intrinsic value, and to explore new markets where competition and productivity are still below the normal standard. In addition, companies looking to create value through mergers often perceive either operational or financial synergy.

Both operational and financial synergy through privatisation can be seen as attractive, as the process offers various opportunities such as entry to new markets and the transfer of technology. Management skills will likely improve as a result of mergers in postprivatisation performance. Cost control also would be a major outcome of this process. Although merger and acquisition decisions could come along with a pile of positive outcomes, priorities and cost-benefit analysis by both management and shareholders in a developing country should differ, particularly when top and middle bank management are foreign employees searching for better income. The advancement in technology, the emergence of the information age, the globalisation of financial products, and the use of sophisticated financial and banking instruments have all combined to precipitate the emergence of banking challenges that have led to a greater extent of banking competition than has ever been seen in banking history. The advancement of banking services and globalisation has brought with it an unprecedented global interdependence, and has brought banking competition to an area of the world in which the banking sector has by and large not completely benefited from these developments.

The latest surge in the number of mergers in the banking sectors in different parts of the world has provided a unique opportunity for the banking sector in many Gulf countries to improve its financial structure and expertise through mergers and acquisitions in an attempt to prepare for the challenges of globalisation. A recent assumption by some economists showed that globalisation is the path for a more integrated equitable world in terms of resources, products, and welfare. It is this argument that the banking sector in a country like Kuwait must grasp in order to understand and prepare for challenges yet to come. Therefore, the merger decision is a phenomenon rather than a creed, and the banking sector's response to it will determine the future shape of Kuwaiti economy. Why were Kuwaiti local banks so reluctant to follow this strategic approach? There is much to discuss in this regard, as time could show the real cost for some banks to avoid such imperative choice.

\section{The effect of globalisation on mergers}

Globalisation can be defined as the process of integrating several economies into one global economy. Within this context, financial markets, at a later stage, will merge to form a huge market where state-of-the-art technology and advanced financial products should provide banks with a high degree of competitive edge. Young financial markets like the Kuwaiti market should face serious competition from large foreign investment and commercial banks because the financial structure for local institutions is still in its preliminary stage. In this regard, two major issues that must be raised are whether local banks are well enough prepared to compete and whether they can survive in the global economy. Globalisation means that local banks have to provide competitive prices through advanced services and products. Arriving at this level of customer satisfaction, banks must employ new competitive standards that are currently 
unavailable. Despite the fact that some economists and politicians are not in favour of this inevitable global market, there is much to be said in support of globalisation:

1 The concept of monopoly should change, as a nation that has absolute or comparative advantage will be affected by the abolition of boundaries and quotas. The absolute or comparative advantage will become more advantageous to one nation compared to another, as the economic structure allows for more freedom and better business opportunities.

2 Globalisation can lead to an extensive fall in trade barriers, capital movements, and a wide variety of investment opportunities that do not exist in other parts of the globe.

3 Globalisation has spurred on the integration of the global economy, which in turn should lead to better economic developments in poor areas and increase wealth distribution.

As a result, various barriers at a certain level of economic deregulation must lead to more openness and less control on foreign investment in various areas of the economy, specifically in the banking system. Understanding differences in cultures and social barriers can also pinpoint some of the difficulties facing the banking system. There is no doubt that the shareholders' structure in the Kuwaiti banking system is a major obstacle to bank mergers, for the following reasons. First, within the federation of the seven Emirates, each local government owns a majority share in more than one bank.

Secondly, in most large banks, the majority of shares are in the hands of a few investors.

Thirdly, the market capitalisation of these banks is extremely low, which enforces our idea that family and special interest groups have no interest in changing the status. Fourthly, foreign ownership so far is not allowed for non-locals.

\section{KUWAIT BANKING FINANCIAL ANALYSIS}

This section attempts to demonstrate various analytical procedures that can be used to evaluate the data contained in banks' financial statements (see Appendix A). It is crucial to emphasise that the data provided in this section were sometimes hard to obtain and, generally, the only data available to us were taken from the usual annual reports. Most details provided here are based on our own analysis. Given accurate financial data, the techniques that we used should provide analysts with considerable insight into the financial structure of Kuwaiti domestic banks and the risk/return characteristics as per bank and for the entire industry, excluding foreign subsidiaries.

In combination, the information derived from banks' financial statements, the analysis of key financial and operating ratios, and statements of cash flows can be important in identifying major areas of strength and weakness for the banks included in our analysis, given the fact that financial transparency (continuous flow of information to the public) is one of the business essentials that banks in Kuwait do not apply in their financial declarations. The aggregate balance sheet of banks operating in Kuwait had grown by 6.8 per cent by the end of 2007 . Deposits and cash with the central bank had reached 1.1 billion by the end of the same year. Net foreign assets of banks had increased by 3 per cent. Credit extended by banks also increased by KD 1.03 billion (6.9 per cent). A great percentage of increase in credit went to 
residents, to reach 6.7 billion (see Appendix A, Tables A1, A7). A bank's performance must be directed towards a specific objective. A fair evaluation of the performance of any bank should start by evaluating whether it has been able to achieve the objectives chosen by its management and stockholders. In the Kuwaiti banking sector, it is obvious that all domestic banks except two had a single main objective: delivering the maximum earning per share. Certainly, many banks have their own unique objectives. Some wish to grow faster and achieve some long-range growth objectives. Others seem to prefer to minimise risk, conveying the image of a sound bank but with modest rewards for their shareholders. Earnings, dividends, and cash flow, provided in Table A1, can easily demonstrate the ideas of different bank objectives. $^{28}$

Obviously, an analysis of banks' profitability tells us much about the causes of banks' earnings fluctuation and suggests where management needs to look for possible cures for any earnings problems that surface. Although the directive of a stock price is the best indicator of a firm's performance because it reflects the market evaluation of the bank's performance, this indicator is often unreliable in banking. Interpreting Profitability Ratios, each foregoing ratio looks at a slightly different aspect of bank profitability. Thus, ROA (return on assets) is primarily an indicator of managerial efficiency; it indicates how capable the management of the bank has been in converting its assets into net earnings. ROE (return on equity), on the other hand, is a measure of the rate of return flowing to the shareholders of the bank; it approximates the net benefit that stockholders have received from investing their capital in the bank (Kuwait Bank Research). The net operating margin, net interest margin, and non-interest margin are efficiency measures as well as profitability measures, indicating how well management and staff have been able to keep the growth of revenues (which come primarily from the bank's loans, investments, and service fees) ahead of rising costs. The year 2007 witnessed an increase in profitability for most local banks.

The rise in profitability was mainly the result of a rise in capital investments and government spending due to the high volatility in international oil prices. The continuous volatility in stock prices and in capital expenditure has contributed to the decline in profitability. In fact, both ROA and ROE were up in 2007, as shown in Appendix A. The decline in both ROA and ROE has gone up on aggregate by almost 12 per cent. The analysis of the banks' balance sheet in general shows that the high rise was due to (1) increase in net interest income on average assets, (2) selling and administrative expense increasing by almost 5 per cent, (3) provision for loan losses increasing by, on average, 1 per cent over the past three years, and (4) the small growth in assets having little impact on improving ROE. In comparison to many international banking systems, Kuwaiti domestic banks still hold a positive ROE and ROA by almost 12 and 2.5 per cent, respectively - higher than the average of the GCC countries. Banks today are under great pressure to meet the objectives of their stockholders, and to take advantage of an exceptional growth rate that might seem unsustainable for a long period, while keeping regulators satisfied that the bank's policies, loans, and investments are sound.

Undoubtedly, the analysis of banks' profitability measures and their respective constituents can indicate much about the reasons of banks' high earnings, suggesting that the 
management must always target long-term goals if they wish to maintain this incredible growth rate in earnings.

Banks are not, however, keen to take drastic steps to stay financially sound, as the gap between management and owners is widening. There is a need to look for a possible remedy for any earnings problems that do surface. The following analysis reminds us that achieving superior profitability for a bank depends on several crucial factors:

1 Careful use of financial leverage (or the proportion of bank assets financed by debt as opposed to shareholders' equity capital).

2 Careful use of operating leverage from fixed assets (or the proportion of fixed-cost inputs the bank uses to boost its operating earnings for taxes as bank output grows).

3 Careful control of operating expenses so that more dollars of sales revenue become net income.

4 Careful management of the asset portfolio to meet liquidity needs while seeking the highest returns from any assets acquired.

5 Careful control of the bank's exposure to risk so that losses do not overwhelm its income and equity capital.

The objective of maximum profitability with a level of risk acceptable to the owners of the bank is not easy to achieve, as the recent upsurge in bank failures around the globe clearly suggests. Aggressive pursuit of such an objective requires an institution to be continually on the lookout for new opportunities for further revenue growth, greater efficiency, and more effective planning and control.
The analysis of reserve/net loans and advances also gives an indication of the management's perspective of risk. In 2007, on average, 66.2 per cent of the assets of local banks were in the form of loans and advance (Table A7). While a few banks underutilised their assets, others continued to carry out more aggressive lending. Given the fast-changing banking environment, credit risk extends beyond conventional credit products such as loans and letters of credit. Banks are taking on additional risk in the form of transactions in the equity market that expose them to counter-party risk and can be difficult to measure. They may also be engaged in taking on credit risk in its more subtle forms. For instance, banks often underestimate the credit risk that arises from off balance sheet financing, taking into consideration the general economic conditions over the past three years (2004 to 2007). Market risk also remains high. The surge in the Kuwaiti equity market over 2006/2007 had led to a great deal of volatility and fluctuation in bank profitability. A large number of investors borrowed heavily from banks to invest in what they thought was a lucrative stock market.

The decline of the Kuwaiti equity market has exposed commercial banks to some irrational lending due to the high credit exposure to many customers who invested heavily in the stock market. These customers have been much more reliant on the utilisation of bank lines of credit to meet their financial obligations. Operational risk is also a growing concern for the banking industry due to the fast growth in business and the mounting concentration of payment settlements, mainly in large-sized banks. Those institutions are exposed to the probability of a high risk resulting from an inefficient internal control system. Further, more banks are forced 
by competition to invest in more advanced technology as they try to keep pace with other banks. An obstacle to this is that of information risk and a risk factor is the inability to develop and maintain a strong enough financial surveillance system to control their assets' users. In addition, most banks have lower loan-deposit ratios than required by the Central Bank. The extent to which individual banks gain will depend on their composition of deposits. Therefore, banks whose deposits are large enough or have access to government deposits will benefit most. There exists a trade-off between liquidity and profitability. Lower or higher liquidity tends to be associated with higher (lower) returns, if banks are able to maintain the quality of their assets (see Table A4).

Table A5 shows that small banks are the most aggressive (high loan-deposit ratios), followed by medium-sized banks. Small banks are the most aggressive, with loan-deposit ratios equalling one or higher. On the other hand, large banks are the most secured, with loan-deposit ratios around 50 per cent. In many cases, banks carry more than one risk at the same time, which means that risks can be interrelated, similar to market risk, which can raise credit risk. Credit risk may derive from operation risks, embedded in complex systems for managing intra-day funding, which requires a rigorous internal control environment. The best way for all banks to protect themselves is to identify risk correctly. Risk control can never be successful without banks changing their credit philosophy. The risk of personal loans is mounting everyday. Banks and financial institutions dangle bait in the form of easy loans and people with unending material desire like to get involved. In fact, some people call it 'the debt traps' (see Business News, October, 1999). This easy policy of providing personal loans to people residing in Kuwait has prompted people to obtain loans to satisfy their luxury needs. Further, banks offer more loans to Kuwaiti nationals because they believe they enjoy better job security and there are fewer chances of them fleeing the country. Clearly, a high income and a better quality of life are the major reasons for many consumers feeling they should profit from the 3 per cent tax on merchandise and zero income tax.

What adds to the problem is that banks always come up with new imported ideas to lure more consumers to borrow more. The limit on personal loans can be as high as three times the individual's monthly salary. It is obvious the limit is not strongly enforced by banks. The latest financial statistics have shown that a staggering 60 per cent of Kuwaiti households are in debt. Therefore, failure to repay loans and criminal actions are posing serious threats to social stability in the country. In 2007, the number of defaulters doubled and the total personal loans reached KD 5.9 billion out of total loans of KD 9 billion. At the same time, loans extended for trade purposes have gone up. Given the fact that banks are targeting short-term objectives, a particular challenge is to relate credit risk assessment to appropriate capital levels, especially given the aggressive nature of their business. Banks operating in Kuwait must maintain a capital adequacy ratio of 10 per cent. Each bank capital requirement will be based on its risk. The risk-based standard requires less capital for loans to governments and financial institutions than for corporate, and deems lending in GCC and OECD countries less risky than lending elsewhere. One possible explanation is the 
exceptional economic growth rate in most Gulf countries.

Obviously, the lack of well-defined credit policies in Kuwait has led banks to apply an aggressive lending approach that makes no distinction between business sectors and the quality of loan users (firms). This forced banks to lend to riskier borrowers, because while such loans may command higher interest rates, they do not force banks to tie up more of their shareholder capital against it. In other words, some banks are forced to hold more capital than they need, while others are encouraged to hold less. These credit standards should improve credit control and reduce risk. In spite of this, banks in Kuwait were able to meet the minimum capital adequacy of 10 per cent. Small-sized banks seem to be better capitalised than largesized banks in terms of the equity-capital ratio (shareholder equity assets), due to their small assets base. On the other hand, banks were successful in reducing capital risk compared to assets, as they shifted most of their earnings into retained earnings and later to free shares (see Table A5).

Since management and shareholders are giving greater importance to returns, this might be difficult to sustain, if the economy is not growing fast, and credit can get riskier. A major solution through which banks can improve returns would be by cutting costs. While most banks were unable to cut operating costs in 2006, a few were able to reduce efficiency ratios (operating cost/total income) by keeping noninterest income levels up. Most banks experienced an increase in costs, marginally pushing up operating efficiency ratios to 32.1 and 36.7 per cent. A few banks saw operating expenses decline by 8 per cent and consequently operating efficiency declined from 41.2 to 38.3 per cent, leaving them better off than in 2005. Hence, bank mergers seem to be the ultimate solution to increasing operating expense. Since mergers and acquisitions reduce costs due to economies of scale, they could also reflect the compulsion to seek protection against the prospects of lower earnings and increased risk factors.

In an effort to diversify their sources of income and assets, various banks have developed their asset management business, since it carries less risk and is considered relatively lucrative compared to other banking fields such as investment banking. Therefore, banks have begun shifting into asset management, as the shift to private banking seems difficult to accomplish. Clearly, this expansion is still constrained by the nonactive capital market, since the shift towards better transparency and the liberty for foreign investments to flow in is not the major priority for Kuwaiti financial authorities. Further, the corporate bond market is almost nonexistent in Kuwait.

According to the average price-earning ratio of this sector, most banks, if not all, seem to have a low ratio, which shows that share prices are undervalued, since shares have been subdued in Kuwait for the past three years. This confirms some of our observations on the banking system: first, that market capitalisation is very low, which shows that a small number of owners, who have no interest in selling, hold shares; secondly, that shareholders are more interested in operating earnings than the capital gain itself; and thirdly, that despite the very low share prices, owners are not exposed to business takeover, as market rules provide safety to shareholders by not allowing foreign investment in this market. 


\section{EMPIRICAL STUDY}

A market survey of 25 questions was presented to 20 chief executive officers of all the national banks existing in Kuwait. Undoubtedly, the sample is relatively small, but it covers all the national banks in the country. There are, however, several observations that we believe should be clarified before we present our empirical evidence.

- Unlike other studies, we believe that only chief executive officers can give true assessments for our market study, as the merger decision is always handled and treated on such a managerial level.

- The sample has excluded all foreign banks because, although they outnumber national banks, they still function as subsidiaries for foreign regional and international banks, and they have no decision to make on any consolidation strategy.

- Our sample covers all banks that have the potential to merge (all the population), and for this reason we believe that there is no need to include branch managers in our sample for the purpose of increasing the sample size. The sample is inclusive to all banks that are considered subject to consolidation.

Through this survey, we attempt to highlight and pinpoint the corporate standpoint on such a strategic and vital decision as a merger.

Previously, most of our discussion has revolved around the various motives of the acquiring bank to initiate a merger. While a merger may be directed towards higher efficiency and less cost through either horizontal or vertical integration, and a possible synergistic effect, banks in Kuwait are still reluctant to initiate any merger deal. Therefore, the following observations attempt to determine the possible barriers to strategic alliance. As indicated in the tables provided in this section, by the 25 variables that we presented to national banks' CEOs and through the statistical analysis of variables, we were able to put forward the following observations.

When bankers were asked whether they had a clear idea of the banking laws and their explanation of merger activity in Kuwait, it was evident that bankers were not sure whether the laws favour consolidation, and some of them were unable to give a better reading of certain banking laws. Inherent throughout our study is the importance of the ownership in many domestic banks and its role as a merger barrier for any future consolidation. The statistical result on this point gave us a mean of 2.88 and a median of 3.00; there is no doubt that in many banks state ownership represents an obstacle to a merger, but not a major one. ${ }^{29}$

As for privatisation and its role in restructuring the banking sector, more than 95 per cent of bankers considered that without serious privatisation decisions, it is mostly impossible to initiate merger attempts. This conclusion seems to point out that government ownership is a major barrier to any potential consolidation. Further, this observation should give more support to the fact that state ownership is a major obstacle rather than a minor one. The study also shows a strong and positive relationship between stock exchange performance and market capitalisation. The merger appears to represent a desirable choice for bankers; a mean of 5.412 showed that most bankers notice the high operating cost due to overbranching, which is a major 
characteristic of the Kuwaiti banking system (see Appendix B).

As efficiency improvement and cost reduction are directly related, both observations (6 and 7) confirm that (with both mean and median close to 5.0) most banks strongly agree that the choice of merger can represent the best alternative to achieve their long-term goals. To the extent that we emphasise the importance of a merger in improving competitive edge and profitability, variables 8,9 , and 10 confirm that foreign subsidiaries are causing them tremendous loss in revenues and merger decisions 'should be' a major strategic objective, which indicates that so far it has not been considered by shareholders and for the most part boards of directors as a possible solution to the high degree of competition. Banks also admit that technology is becoming a heavy burden, since competitors (mainly foreign subsidiaries) have cheaper access to it and to other banking products. The observation and the dispersion of answers in variable 11 do not, however, imply that a merger is a great solution to the high cost of technology.

Given the fact that Kuwait is preparing to join the World Trade Organization (WTO), which must lead to a complete liberalisation of markets, rules, and structure, the answer given by our sample, with a mean of 3.235 and a low standard deviation of 0.664 , shows that most banks do not give serious thought to this matter. On the other hand, the sample seemed to support the fact that such drastic change would have an effect on the current shareholders' structure, which is characterised by a small shareholders' base.

Moreover, the observation and the dispersion of answer in variable number 13 did specify that the exceptional growth in revenues realised by all banks in Kuwait (in a banking sector where we have no losers), the question of keeping the status quo in ownership and market share per bank seem to pose an important obstacle in the face of any merger attempt. More relative observations to the aim of this research were directed to the questions of family ownership and the management of public shareholding businesses as privately owned firms.

In this regard, the sample that covers all domestic banks has provided strong proof of the fact that most domestic banks in Kuwait are still controlled and managed by their founders as a family business, given the fact that the 'shareholders' base is very small (see variable 14). Clearly, the ownership structure still poses a major barrier to any potential merger in an emerging market like Kuwait. It is possible to add that this observation is general and applies on most corporations in the area and the Arab World in particular. The managerial style and structure always decide the future of any company.

Furthermore, there is a large gap between any management and the board of directors when it comes to strategic planning. The latter is true given the results of two observations: corporate mentality in Kuwait (variable 15) and management structure in Kuwait (variable 16). Both observations indicated that foreign direct investment in most sectors of the economy still faces strong rejection. The other point, which also received some support, is the fact that almost all national banks have the control of foreign management. This managerial structure forces the surfacing of management and ownership through agency theory (see Table B3, Appendix B). In regard to many observations related directly to the merger process and the possible barriers, we have the following observations: (a) the results gave strong support (mean 5.106 and St. deviation of 
0.114) for the fact that in-market consolidation is the best choice for national banks, (b) the sample rejected cross-border consolidation as an absolute success for national banks with mean 2.412, median 2.000, and standard deviation of 0.150 , (c) the results showed an absolute rejection to the fact that the banking system is well prepared to face foreign competition in case Kuwait joins the WTO in the near future (mean 2.529, median 2.00, a standard deviation 1.007), (d) the sample showed that the banking industry still considers the merger and acquisition process (to a certain extent mean 2.882) as an aggressive banking strategy that carries a high degree of risk. The survey also indicated that there is a direct link between the delay in banking consolidation and the less developed (dormant) money and capital markets. This point could also highlight the fact that the financial market is not well prepared to handle and react to any merger attempt. In sum, the sample showed that the structure of the Kuwaiti banking system created various kinds of barriers, so as to stop any possible attempt to break through the current ownership structure banking consolidation. In sum, Kuwaiti financial structure still rejects foreign direct investments, and for that reason many economic and social barriers were put in place.

With reference to Table B6, we can clearly summarise the following:

First, value number $(6=$ agree $)$ has received 32 per cent approval from the sample mentioned before, and 24 per cent was given to value number $(5=$ strongly agree), which shows strong confirmation of the majority of observations given in our survey. Secondly, as for the other values, only a small percentage of 8 per cent was given to value number ( $2=$ disagree), and 32 per cent to value number $(3=$ agree to a certain extent), which also shows that despite the different origin of those who were included in our sample (CEOs), the study still gives strong positive results to our observations. Thirdly, undoubtedly, even by excluding value number ( $3=$ agree to a certain extent) the final result shows 56 per cent to agree and strongly agree against only 8 per cent to rejection (disagree), which by far gives better results to this survey. The figures basically show that the majority of CEOs tend to approve our analysis and diagnosis of the current status of the Kuwaiti banking system for most of the questions provided in our study. As for the remaining answers, 36 per cent fall between what we considered neutral to agree to a certain extent (see Appendix B). Further, in an effort to give more support and accuracy to the previous results, the results given under SE mean clearly indicate that the deviation from the mean on all variables was very minimal, which justifies the coherence of most SE mean values extracted from our survey. The answers given by the CEOs in the study and their statistical calculations showed strong relevance to our earlier observations. On the other hand, as the spread between the mean and median was extremely tight and since the mean is the indicator that shows more of variation, it was the focus of our previous analysis in an effort to indicate the main concentration in results.

\section{CONCLUSION}

Several conclusions come from the evidence analysed in this study. First, there is no doubt that the corporate mentality in Kuwaiti banks has not evolved well, as the short-term benefits are considered more important than any other long-term strategic decision. Secondly, banks are 
reluctant to take what they may perceive as pioneering, strategic decisions without serious liberalisation of the financial system of the country in question. In the future, the notion of mergers and banking integration will most likely become more comprehensible, as the deregulation of most financial services, the opening of markets for foreign investments and equity ownership, and fierce competition would all lead to successful banking mergers. Thirdly, the notions of operating efficiency, employee productivity, and cost reduction are not at the top of banks' lists of priorities that can be achieved through a merger. This is a manifestation of the banks becoming less adapted to cost control. Fourthly, according to our statistical analysis, what might seem, in terms of financial strategies, suitable for most developed banking systems in the west, these strategies are in many cases rejected by less developed banking systems because they pose serious threats to most large shareholders. Deregulation, foreign investments, and globalisation are notions that are socially and economically rejected in the Gulf countries.

Boards of directors in many cases have been ineffective in defining the main issues and challenges confronting their business, as the general economic conditions are still in their favour. Management ownership in banks should increase their commitment to long-term strategic objectives, and improve the convergence of interests with shareholders. Therefore, deviation from value maximisation would decline, and the question of improving efficiency, competition, and reducing operating expense would require more strategic planning. In the case of the Kuwaiti banking sector, management can never be qualified to have more participation in strategic decisions, as investment laws forbid foreign ownership in public shareholding companies. Equity ownership concentration and market capitalisation are two important financial measures that move in tandem. Unlike the most developed financial markets, emerging markets tend to have high concentration in equity ownership and weak management ownership. A simple outcome of this correlation is an illiquid stock market and subdued share prices. This is the case of the Kuwait stock market. Kuwaiti domestic banks must reduce their reliance on foreign management to run their local operations. The concept places management in the agency position of making decisions on behalf of shareholders and in their best interest. Therefore, as banks move seriously into merger and acquisition, the agency theory should become more useful in assessing the effectiveness of management in achieving shareholders' longterm objectives.

\section{References and Notes}

1 Keefe, Bruyette, and Woods and Ernst and Young (1990) 'The Economic Effects of Mergers and Acquisitions on Consolidating data and Operation Centers', Keefe, Bruyette, and Woods and Ernst and Young, USA.

2 Houston, I.F and Ryngaert, M.D. (1994) 'The Overall Gains from Large Bank Mergers', Journal of Banking and Finance, Vol. 18, pp. 1155-1176.

3 Cost reduction is becoming the cornerstone of most bank mergers as competition is putting pressure on revenues.

4 Local bank employees represent on average not more than 15 per cent of the total banking population. There are 135 different nationalities residing in the UAE.

5 Dymski, G.A. (1999) 'The Bank Merger Wave: The Economic Causes and Social Consequences of Financial Consolidation', M.E. Sharpe, Armork, NY and London, UK.

6 See Gary Dyrnski’s book on merger wave in 1999.

7 Calomiris, C.W. (1999) 'Gauging the Efficiency of Bank Consolidation during a Merger Wave', Journal of Banking and Finance, Vol. 23, pp. 615-621. 
8 Calomiris, C. W. (1998) ${ }^{9}$ (Gauging the Efficiency). Case studies have made the writer sceptical of a great deal of the empirical literature used to measure the average gains from the consolidation wave.

9 Calomiris, C.W. (1998) 'Universal Banking American Style', Journal of Institutional and Theoretical Economics, Vol. 154, pp. 44-57.

10 For more discussion on this matter, see Berger et al. (1993a), and Necmi Kemel Avkiran. ${ }^{11}$

11 Avkiran, N.K. (1999) 'The Evidence of Efficiency Gains: The Role of Mergers and the Benefits to the Public', Journal of Banking and Finance, Vol. 23, pp. 991-1013.

12 Equity ownership by managers must balance convergence or an alignment of interest versus entrenchment consideration. Stul $z^{13}$ has used a model to show that management and shareholders interest will tend to converge even at a low level of management ownership.

13 Stulz, R.M. (1988) 'Managerial Control of Voting Rights, Financial Policies and the Market for Corporate Control', Journal of Financial Economics, Vol. 20, pp. $25-54$.

14 Economists like Ravenscraft and Scherer ${ }^{15}$ advocated that merger is regarded a purging exercise where incompetent management is replaced and translates into a search for efficiency gains through cost saving.

15 Ravenscraft, D.J. and Scherer, F.M. (1987) 'Merger, Sell Offs, and Economic Efficiency', Brooking Institutions, Berkeley, CA.

16 Linder, J. and Crane, D. (1992) 'What it Takes to Make Bank Mergers Pay', American Banker, July.

17 Rhoades, S.A. (1998) 'The Efficiency Effects of Bank Mergers: An Overview of Case Studies of Nine Mergers', Journal of Banking and Finance, Vol. 22, pp. 273-291.

18 Rhoads argues that there is a continuing disagreement between systematic studies and views given by bankers on merger outcomes in particular.

19 Guzman, M.G. (2000) 'The Economic Impact of Bank Structure: A Review of Recent Literature', Economics and Financial Review, Second Quarter, Vol. 51, pp. 11-25.

20 Kay, J. (1993) 'Foundation of Corporate Success', Oxford University Press, Oxford.
21 Jatusripitak, S., Fahey, L. and Kotler, P. (1985) 'Strategic Global Marketing: Lessons from the Japanese', Columbia Journal of World Business, Vol. 20, No. 1, pp. 47-53.

22 Necmi Avikiran has used Sinkey's comments 1983, p. 21 on using ROA and ROE as best rules to measure bank's performance, they have looked at the relationship between controlling cost and improving ROA and ROE.

23 Maintaining the identity and objectives of the company and making sure that they continue to be relevant to the old identity and that objectives are crucial for bankers.

24 We could also attribute the scarcity of bank mergers on the regional and local level to the difficulty of understanding the long-term advantages of mergers as owners have short-term objectives. Some of these major objectives can be summarised into two points: to reap the maximum financial profits in addition to the socio-economic factors becoming a major cause of concern for companies in this changing environment in which owners can benefit from.

25 Uhlenbruck, K. and De Castro, J. (1998) 'Privatization from the Acquirer's Perspective: A Mergers and Acquisitions Based Framework', Journal of Management Studies, Vol. 35, pp. 619-640.

26 Uhlenbruck and De Castro ${ }^{25}$ claim the researchers support the hypothesis that the key issue in privatisation in developing countries is not ownership as much as managerial accountability that could fundamentally distinguish public from private enterprise and cause the inefficiency of many state-owned firms.

27 Haspeslagh, P. and Jemision, D.B. (1991) 'Managing Acquisitions: Creating Value Through Corporate Renewal', Free Press, New York.

28 As this strategic decision is becoming inevitable for some banks, the response to it is extremely slow despite the public and official support to it.

29 This point cannot be applicable to all cases as some mergers might have efficiency improvement on top of its priorities. Nevertheless, the stock market seems to have reflected its doubts about the outcomes of inmarket bank mergers through the heavy selling of the acquirers' shares and consequently the drop in the value of its share price. 


\section{Appendix A}

See Tables A1-A9.

Table A1: Banking market share and position

\begin{tabular}{|c|c|c|c|c|c|c|}
\hline & \multirow[b]{2}{*}{ Deposits (KD m) } & \multicolumn{2}{|c|}{ Deposit gathering } & \multirow[b]{2}{*}{ Loans $(K D \mathrm{~m})$} & \multicolumn{2}{|c|}{ Credit extension } \\
\hline & & Mkt shr. $(\%)$ & Mkt. position & & Mkt shr. $(\%)$ & Mkt. Position \\
\hline \multicolumn{7}{|c|}{ National banks ${ }^{\mathrm{a}}$} \\
\hline 1. GB & $1,502,356$ & 21.08 & 3 & 501,681 & 17.19 & 4 \\
\hline 2. $\mathrm{NBK}$ & $2,565,542$ & 15.34 & 1 & 990,465 & 6.86 & 2 \\
\hline 3. $\mathrm{CB}$ & 961,390 & 0.79 & 4 & 281,034 & 1.55 & 7 \\
\hline 4. $\mathrm{BB}$ & $502,2 \mathrm{G} 3$ & 1.24 & 7 & 907,743 & 1.38 & 3 \\
\hline 5. BKME & $1,109,783$ & 1.36 & 5 & 101,575 & 1.05 & 8 \\
\hline 6. $\mathrm{AB}$ & 901,605 & 1.04 & 6 & 250,761 & 1.23 & 6 \\
\hline \multicolumn{7}{|l|}{ Islamic banks } \\
\hline 7. BO.B & 498,667 & 1.24 & 8 & 272,955 & 0.27 & 5 \\
\hline 18. KFH & $117,627,124$ & 6.30 & 2 & $1,063,219$ & 9.29 & 1 \\
\hline
\end{tabular}

${ }^{\mathrm{a}}$ Bank names are put in initials only.

Table A2: Major profitability ratios

\begin{tabular}{|c|c|c|c|c|c|c|}
\hline & \multicolumn{3}{|c|}{ Return on average assets (\%) } & \multicolumn{3}{|c|}{ Return on average equity (\%) } \\
\hline & 2007 & 2006 & 2005 & 2007 & 2006 & 2005 \\
\hline National banks: Average & 3.70 & 3.00 & 2.44 & 16.1 & 15.44 & 14.23 \\
\hline Islamic banks: Average & 4.02 & 3.78 & 2.01 & 5.62 & 2.66 & 1.54 \\
\hline Total average & 3.86 & 3.39 & 1.22 & 10.86 & 9.05 & 7.88 \\
\hline
\end{tabular}

This table is a summary of major ROA and ROE per banking specialisation. 
Table A3: Banking sector stock ratio analysis

\begin{tabular}{lcccccccc}
\hline $\begin{array}{l}\text { 30th November, } \\
\text { 2007 }\end{array}$ & EPS & BVPS & $\begin{array}{l}\text { PS } \\
(\mathrm{X})\end{array}$ & $\begin{array}{l}\text { PIE } \\
(\mathrm{X})\end{array}$ & $\begin{array}{l}\text { P/BV } \\
\text { yield }\end{array}$ & $\begin{array}{l}\text { Divided } \\
(\%)\end{array}$ & $\begin{array}{l}\text { Payout } \\
(\%)\end{array}$ & $\begin{array}{l}\text { Sustainable } \\
\text { growth (\%) }\end{array}$ \\
\hline $\begin{array}{l}\text { National banks: } \\
\text { 1. GB }\end{array}$ & 42,4 & 267.6 & 20.0 & 12.85 & 2.04 & 3.7 & 47.2 & 8.7 \\
2. NBK & 46,2 & 428.0 & 40.0 & 18.49 & 2.00 & 4.7 & 86.5 & 1.5 \\
3. CB & 1.0 & \multicolumn{1}{c}{42} & 0.0 & 11.80 & 2.75 & 0.0 & 0.0 & 26.4 \\
4. BB & 5.3 & 149.3 & 10.0 & 54.90 & 1.94 & 3.4 & 189.3 & -3.1 \\
5. BKME & 1.7 & 16.3 & 1.2 & 17.49 & 1.59 & 4.1 & 72.4 & 2.7 \\
6. AB & 21.2 & 150.8 & 18.0 & 13.16 & 1.66 & 6.4 & 84.7 & 2.2 \\
& & & & & & & & \\
Average & & & 13.18 & 2.40 & $2.5 \%$ & & 40.8 & 9.6 \\
\hline
\end{tabular}

Table A4: Banking sector deposit and credit size

\begin{tabular}{|c|c|c|c|c|c|c|}
\hline & \multirow{2}{*}{$\frac{\text { Deposits }}{2007}$} & \multicolumn{2}{|l|}{ Gross L\&A } & \multicolumn{3}{|c|}{ Past due loans } \\
\hline & & $2007 a$ & $2007 b$ & 2006 & 2005 & $2007 \mathrm{a} / \mathrm{b}$ \\
\hline \multicolumn{7}{|c|}{ National banks } \\
\hline 1. GB & $1,502,010$ & $1,401,681$ & 706,707 & 170,147 & NA & 1.04 \\
\hline 2. NBK & $2,565,542$ & $2,010,465$ & 126,672 & 360,222 & NA & 4.81 \\
\hline 3. CB & 961,390 & 561,034 & 220,699 & 251,020 & 242,686 & 1.96 \\
\hline 4. $\mathrm{BB}$ & 878,293 & 407,743 & 62,350 & 56.179 & 23,595 & 1.43 \\
\hline 5. BKME & 939,763 & 566,575 & 37,532 & 33,260 & 32,478 & 1.52 \\
\hline 6. $\mathrm{AB}$ & 961,605 & 250,761 & 16,730 & 13,196 & NA & 1.50 \\
\hline 7. $\mathrm{BB}$ & 716,002 & 661,981 & 461,700 & 35,796 & 23,144 & 0.91 \\
\hline \multicolumn{7}{|l|}{ Islamic banks } \\
\hline 8. KFH & $1,096,667$ & 272,955 & NA & NA & NA & NA \\
\hline 9. BO.B & 627,124 & 463,219 & 90,621 & 20,895 & 53,014 & 7.30 \\
\hline Total & 377.933111 & 732.9348 & 712,811 & 164,399 & 768,407 & 5.46 \\
\hline
\end{tabular}


Table A5: Local bank profitability analysis

\begin{tabular}{|c|c|c|c|c|c|c|c|c|}
\hline & \multicolumn{8}{|c|}{ Bank sizes* } \\
\hline & \multicolumn{3}{|c|}{ Large banks (\%) } & \multicolumn{3}{|c|}{ Small banks (\%) } & \multicolumn{2}{|c|}{ Medium-sized banks (\%) } \\
\hline & 2005 & 2006 & Change & 2005 & 2006 & Change & 2006 & Change \\
\hline Net interest income/avg. assets & 2.80 & 2.85 & -0.50 & 4.10 & 4.10 & 0.30 & 3.50 & -4 \\
\hline Non-interest income/avg. assets & 1.30 & 1.50 & 13 & 1.60 & 1.70 & 7 & 1.60 & 2 \\
\hline Overhead expenses/avg. assets & 1.30 & 1.40 & 5 & 2.10 & 2.10 & 3 & 1.90 & -8 \\
\hline Loans loss prov./avg. assets & 0.60 & 0.90 & 34 & 1.50 & 2.20 & 40 & 0.70 & 45 \\
\hline Int.income/avg. assets & 6.60 & 6.60 & -2 & 7.30 & 7.30 & 0.20 & 6.90 & -3 \\
\hline Int.expenses/avg. assets & 4 & 3.90 & -3 & 3.20 & 3.20 & 0.00 & 3.50 & -1 \\
\hline Int.Inc/avg. earning assets & 7.25 & 7.10 & -2 & 7.60 & 7.70 & 1 & 7.20 & -3 \\
\hline Int.Exp/avg. int. bearing liab. & 4.80 & 4.60 & -3 & 4.30 & 4.30 & 1 & 3.80 & -0.20 \\
\hline Spread & 2.40 & 2.40 & 0.20 & 3.40 & 3.40 & 0.40 & 3.30 & -6 \\
\hline Operating profit/avg. assets & 2.80 & 2.80 & 3 & 3.60 & 3.70 & 2 & 3.20 & 2 \\
\hline Operating expense/avg. assets & 1.30 & 1.40 & 55 & 1.90 & 2.00 & 3 & 1.90 & -8 \\
\hline Operating efficiency & 31.70 & 32.30 & 1 & 36.30 & 36.70 & -1.00 & 38.30 & -7 \\
\hline Return on equity (ROE) & 19.10 & 17.70 & -7 & 15.60 & 13.70 & -14.50 & 15.90 & -136 \\
\hline
\end{tabular}

2007 figures are indicated in other tables and if not they are unavailable from the source.

*The figures are segmented as per bank size.

Table A6: Local banks capital adequacy

\begin{tabular}{llllll}
\hline & $\begin{array}{l}\text { Equity capital } \\
\text { ratio (\%) }\end{array}$ & $\begin{array}{l}\text { Gwth rate of } \\
\text { adj. assets (\%) }\end{array}$ & $\begin{array}{l}\text { Gwth rate of } \\
\text { primary capital (\%) }\end{array}$ & $\begin{array}{l}\text { Cash dividends/net } \\
\text { operating income (\%) }\end{array}$ & $\begin{array}{l}\text { Capital } \\
\text { adequacy (\%) }\end{array}$ \\
\hline Large banks & & & & & \\
NBK & 15.10 & 5.70 & 0 & 79.40 & 54.80 \\
GB & 14.30 & 12.10 & 20.90 & 21.70 & 23.70 \\
CB & 12.60 & 9.50 & 25 & 21.10 & 14.40 \\
Average & 12.50 & 12 & 10.20 & 38.60 & 26 \\
Medium banks & & & & & 3.70 \\
BKME & 12.70 & 23.40 & 25.10 & 0 & 18 \\
AB & 16.50 & 27.20 & 12.10 & 35 & 15.90 \\
Average & 14.60 & 25.30 & 18.60 & 17.50 & 3.54 \\
Small banks & & & & & 30 \\
BB & 11.02 & 13.34 & 14.67 & 13.34 & 26.60 \\
Average & 22.60 & 10.90 & 15.50 & 31.70 & \\
Banking sector average & 18.20 & 13.20 & 14.20 & 32.10 & \\
\hline
\end{tabular}


Table A7: Local banks liquidity

\begin{tabular}{|c|c|c|c|c|c|c|c|c|c|}
\hline & \multicolumn{3}{|c|}{ Net LEA/avg. assets (\%) } & \multicolumn{3}{|c|}{ Loan/deposit ratio (\%) } & \multicolumn{3}{|c|}{ Liquid assets/total assets (\%) } \\
\hline & 2005 & 2006 & Change & 2005 & 2006 & Change & 2005 & 2006 & Change \\
\hline GB & 51.90 & 52.20 & 0.58 & 62.80 & 62.40 & -0.64 & 42.50 & 43.80 & 3.06 \\
\hline NBK & 24 & 25.20 & 5.00 & 30.60 & 31.80 & 3.92 & 73.70 & 73 & -0.95 \\
\hline $\mathrm{CB}$ & 69.80 & 73.50 & 5.30 & 90.50 & 95.90 & 5.97 & 19.80 & 21.80 & 10.10 \\
\hline BKME & 63 & 60.45 & 25.24 & 81.20 & 82.90 & 2.09 & 37.70 & 33.60 & -10.88 \\
\hline $\mathrm{AB}$ & 67 & 71.90 & 7.31 & 85.50 & 98 & 14.62 & 35.70 & 29.70 & -16.81 \\
\hline Average & 55 & 56.60 & 2.91 & 70.20 & 74.20 & 5.70 & 41.90 & 40.40 & -3.58 \\
\hline $\mathrm{BB}$ & 75.10 & 82.40 & 9.72 & 81.40 & 86.90 & 6.76 & 18.20 & 19 & 4.40 \\
\hline $\mathrm{BhB}$ & 68.50 & 75.10 & 9.64 & 82.50 & 88 & 6.67 & 32.80 & 28.60 & -12.80 \\
\hline Average & 69.80 & 74.70 & 9.61 & 82 & 87.50 & 6.71 & 25.50 & 23.80 & -6.67 \\
\hline Sector avg. & 60.10 & 78.70 & 30.95 & 76.00 & 85.30 & 12.89 & 37.90 & 33.10 & -12.66 \\
\hline
\end{tabular}

Table A8: Bank sector weighting, assets and debt utilisation ratios

Date: 24-08-2007

\begin{tabular}{|c|c|c|c|c|c|}
\hline Issuing company & Sector weighting (\%) & $P / B$ & Equity/T.A (\%) & Debt/T.A (\%) & Debt/Equity \\
\hline GB & 35.47 & 3.10 & 7.4 & 92.6 & 12.5 \\
\hline NBK & 42.29 & 2.35 & 15.8 & 84.2 & 5.3 \\
\hline $\mathrm{CB}$ & 8.33 & 7.02 & 21.3 & 78.7 & 3.7 \\
\hline BKME & 5.43 & 2.37 & 18.8 & 81.2 & 4.3 \\
\hline $\mathrm{AB}$ & 4.09 & 1.85 & 25.6 & 74.4 & 2.9 \\
\hline $\mathrm{BB}$ & 4.40 & 0.00 & & & \\
\hline EBI & 28.06 & 4.70 & 14.3 & 85.7 & 6.0 \\
\hline Industry average & 95.60 & 3.01 & 13.7 & 86.0 & 7.7 \\
\hline
\end{tabular}

Table A9: Summary of earnings, dividends and free cash flow for national banks

\begin{tabular}{|c|c|c|c|c|}
\hline & Earnings (2007) & Earnings (2006) & Dividend & Free cash flow \\
\hline \multicolumn{5}{|l|}{ National banks } \\
\hline I. GB & 308,905 & 399,206 & 188,320 & $3,528,240$ \\
\hline 2. $\mathrm{NBK}$ & 401,452 & 401,533 & 344,707 & $-511,249$ \\
\hline 3. $\mathrm{CB}$ & 89,783 & 72,739 & 0 & $-19,336$ \\
\hline 4. BKME & 30,040 & 15,846 & 21,000 & $-162,452$ \\
\hline 5. $\mathrm{AB}$ & 49,320 & 41,450 & 37,500 & $-167,300$ \\
\hline 6. BB & 57,262 & 53,106 & 45,000 & 57,601 \\
\hline 7. $\mathrm{BhB}$ & 507,740 & 412,884 & 146,945 & 805,488 \\
\hline \multicolumn{5}{|l|}{ Islamic banks } \\
\hline I. KFH & 17,450 & 103,645 & 105,707 & \\
\hline 2. BoB & 99,297 & $-33,754$ & 50,000 & $-231,311$ \\
\hline
\end{tabular}


See Tables B1-B6.

Table B1: Summary of descriptive statistics on bank M\&A in Kuwait (National Banks' views)

\begin{tabular}{|c|c|c|c|c|c|c|c|c|c|c|}
\hline Variable & $N$ & Mean & Median & Tr.Mean & St Dev & SE Mean & Minimum & Maximum & Q1 & Q3 \\
\hline $\begin{array}{l}\text { 1. Banking and business laws governing } \\
\text { the banking sector in Kuwait facilitate } \\
\text { any attempt by banks to consolidate } \\
\text { through merger \& acquisition? }\end{array}$ & 17 & 3.941 & 4.000 & 3.867 & 0.899 & 0.218 & 3.000 & 6.000 & 3.000 & 4.000 \\
\hline $\begin{array}{l}\text { 3. It is believed that privatisation in } \\
\text { general is imperative for banking system } \\
\text { in Kuwait to consolidate through } \\
\text { merger and acquisition }\end{array}$ & 17 & 5.059 & 5.000 & 5,067 & 0.429 & 0.104 & 4.000 & 6.000 & 5.000 & 5.000 \\
\hline $\begin{array}{l}\text { 4. There is a general consensus that } \\
\text { privatisation should lead to improvement } \\
\text { in stock market performance as it } \\
\text { tends to increase both the shareholders' } \\
\text { base and the market capitalisation }\end{array}$ & 17 & 5.588 & 6.000 & 5.800 & 1.004 & 0.243 & 2.000 & 6.900 & 5.500 & 6.000 \\
\hline $\begin{array}{l}\text { 5. Over-branching is considered one } \\
\text { of the major features of the banking } \\
\text { system }\end{array}$ & 17 & 5.412 & 6.000 & 5.467 & 0.712 & 0.173 & 4.000 & 6.000 & 5.000 & 6.000 \\
\hline
\end{tabular}

$\star$ Agree $=6,{ }^{\star}$ Strongly agree $=5,{ }^{\star}$ To ascertain extent agree $=3,{ }^{\star}$ Missing response $=3,{ }^{\star}$ Neutral $=4,{ }^{\star}$ Disagree $=2,{ }^{\star}$ Strongly disagree $=1$. 


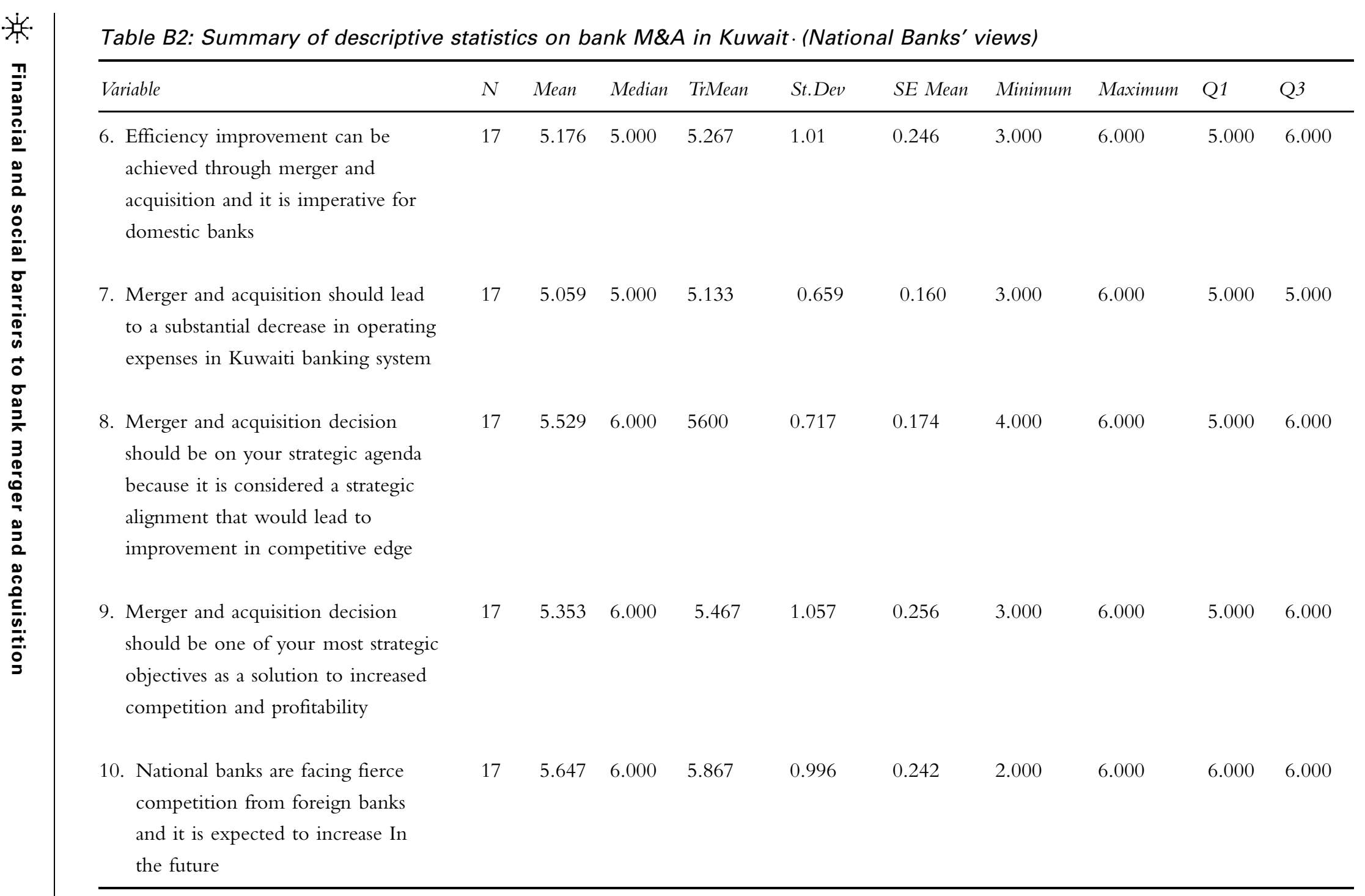

$\star$ Agree $=6, \star$ Strongly agree $=5 ; \star$ To ascertain extent agree $=3$, Missing feedback=3, $\star$ Neutral $=4,{ }^{\star}$ Disagrees $=2, \star$ Strongly disagree $=1$. 
Table B3: Summary of descriptive statistics on bank M\&A in Kuwait (National Banks' views)

\begin{tabular}{|c|c|c|c|c|c|c|c|c|c|c|}
\hline Variable & $N$ & Mean & Median & TrMean & StDev & SE Mean & Minimum & Махітum & Q1 & Q3 \\
\hline $\begin{array}{l}\text { 11. Foreign banks in Kuwait have better } \\
\text { and cheaper access to new products, } \\
\text { technology, and other banking services }\end{array}$ & 17 & 5.765 & 6.000 & 5.933 & 0.752 & 0.182 & 3.000 & 6.000 & 6.000 & 6.000 \\
\hline $\begin{array}{l}\text { 12. Joining the world trade treaty could } \\
\text { cause serious threats to the domestic } \\
\text { banking sector and to the current } \\
\text { shareholders' structure in particular }\end{array}$ & 17 & 3.235 & 3.000 & 3.200 & 0.664 & 0.161 & 2.000 & 5.000 & 3.000 & 3.500 \\
\hline $\begin{array}{l}\text { 13. High revenues in the banking sector } \\
\text { are a major cause for national banks } \\
\text { to avoid consolidation through } \\
\text { merger and acquisition }\end{array}$ & 17 & 2.941 & 3.000 & 2.933 & 0.556 & 0.135 & 2.000 & 4.000 & 3.000 & 3.000 \\
\hline $\begin{array}{l}\text { 14. Family ownership of many domestic } \\
\text { banks is a major cause for these } \\
\text { banks to reject consolidation through } \\
\text { merger and acquisition }\end{array}$ & 17 & 4.765 & 5.000 & 4.867 & 0.903 & 0.219 & 2.000 & 6.000 & 5.000 & 5.000 \\
\hline $\begin{array}{l}\text { 15. The corporate mentality in Kuwait } \\
\text { still rejects foreign direct investment } \\
\text { in national banks and other sectors of } \\
\text { the economy }\end{array}$ & 17 & 5.706 & 6.000 & 5.933 & 0.965 & 0.239 & 2.000 & 6.000 & 6.000 & 6.000 \\
\hline
\end{tabular}

$\star$ Agree $=6$, Strongly agree $=5, \star$ To a certain extent agree $=3, \star$ Missing feedbacks $3, \star$ Neutral $=4, \star$ Disagree $=2, \star$ Strongly disagree $=1$. 


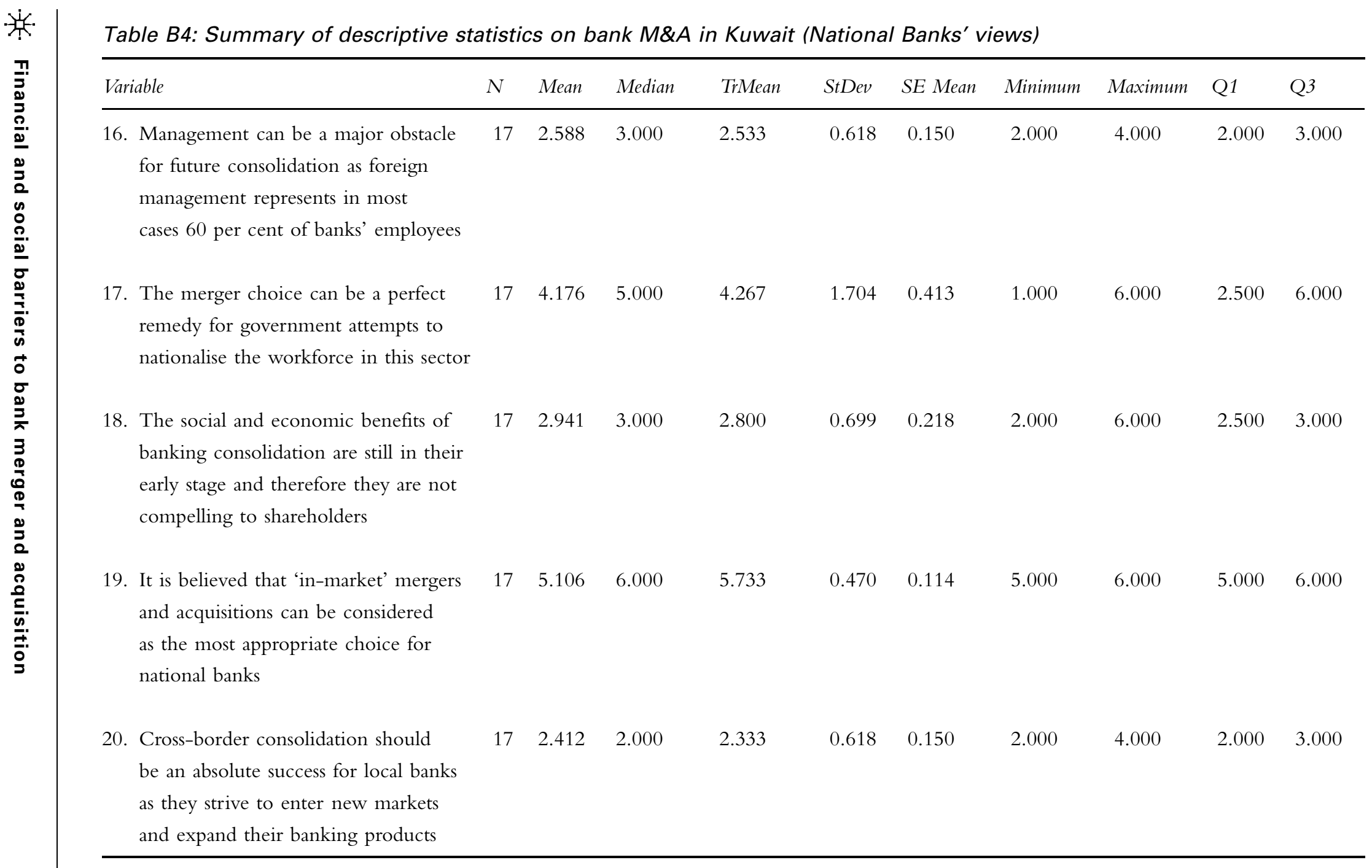

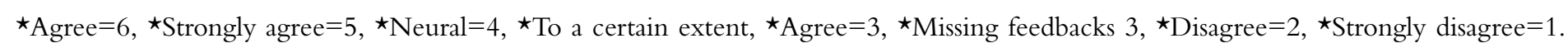




\begin{tabular}{|c|c|c|c|c|c|c|c|c|c|c|}
\hline Variable & $N$ & Mean & Median & Tr.Mean & St.Dev & SE Mean & Minimum & Maximum & Q1 & Q3 \\
\hline $\begin{array}{l}\text { 21. If the United Arab Emirates were to } \\
\text { open its market to foreign competition } \\
\text { by joining the World Trade } \\
\text { Organization, the banking system is } \\
\text { prepared to face foreign competition } \\
\text { and probable takeovers by foreign banks }\end{array}$ & 17 & 2.529 & 2.000 & 2.333 & 1.007 & 0.244 & 2.000 & 6.000 & 2.000 & 3.000 \\
\hline $\begin{array}{l}\text { 22. Economists advocate that international } \\
\text { alliance should improve the financial } \\
\text { structure of the local financial system } \\
\text { and reduce local capital transfer to } \\
\text { foreign markets searching for better }\end{array}$ & 17 & 5.176 & 5.000 & 5.267 & 0.728 & 0.176 & 3.000 & 6.000 & 5.000 & 6.000 \\
\hline $\begin{array}{l}\text { 23. Bankers consider merger and } \\
\text { acquisition as an aggressive banking } \\
\text { strategy that could carry high degree } \\
\text { of risk }\end{array}$ & 17 & 2.882 & 3.000 & 2.733 & 0.928 & 0.225 & 2.000 & 6.000 & 2.000 & 3.000 \\
\hline $\begin{array}{l}\text { 24. Financial authorities conceive merger } \\
\text { and acquisition as an inevitable long-run } \\
\text { banking strategy and that banks should } \\
\text { be prepared for it }\end{array}$ & 17 & 3.412 & 3.000 & 3.333 & 1.004 & 0.243 & 2.000 & 6.000 & 3.000 & 3.500 \\
\hline $\begin{array}{l}\text { 25. As the equity, money and capital } \\
\text { markets are not highly developed; it is } \\
\text { obvious that these conditions have been } \\
\text { delaying any in-market or cross-boarder } \\
\text { alliance through merger and acquisition }\end{array}$ & 17 & 3.353 & 3.000 & 3.267 & 1.115 & 0.270 & 2.000 & 6.000 & 3.000 & 2.000 \\
\hline
\end{tabular}


Table B6: Summary of value distribution for descriptive statistics

\begin{tabular}{llll}
\hline Value & Frequency & Percentage (\%) & Values \\
\hline 1 & 0 & 0 & Strongly disagree \\
2 & 2 & 8 & Disagree \\
3 & 8 & 32 & Certain extent- agree \\
4 & 1 & 4 & Neutral \\
5 & 6 & 24 & \\
6 & 8 & 32 & Strongly agree \\
\hline
\end{tabular}

